Prepared for the U.S. Army Corps of Engineers, Portland District

under an Interagency Agreement with the U.S. Department of Energy

Contract DE-AC05-76RL01830

\title{
Optimization of Hydroacoustic Equipment Deployment at Foster Dam, 2013
}

\author{
JS Hughes \\ GE Johnson \\ GR Ploskey \\ MJ Hennen \\ ES Fischer \\ SA Zimmerman
}

March 2013

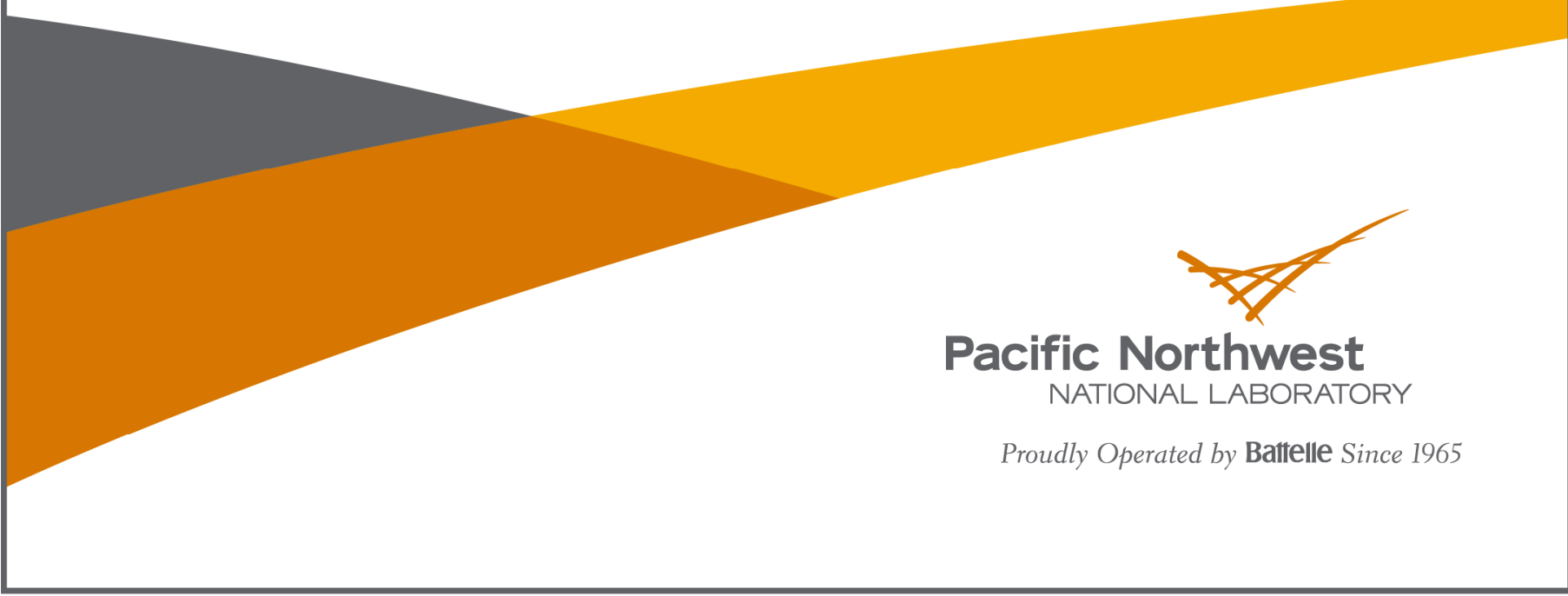




\title{
Optimization of Hydroacoustic Equipment Deployment at Foster Dam, 2013
}

\author{
JS Hughes \\ GE Johnson \\ GR Ploskey \\ MJ Hennen ${ }^{1}$ \\ ES Fischer \\ SA Zimmerman
}

March 2013

Prepared for

U.S. Army Corps of Engineers, Portland District under an Interagency Agreement with the U.S. Department of Energy

Contract DE-AC05-76RL01830

Pacific Northwest National Laboratory

Richland, Washington 99352

\footnotetext{
${ }^{1}$ Pacific States Marine Fisheries Commission
} 


\section{Summary}

This report documents the results of an acoustic optimization study conducted by the Pacific Northwest National Laboratory (PNNL) for the U.S. Army Corps of Engineers Portland District (USACE) at Foster Dam (FOS) during February and March 2013. The goal of the study was to optimize the performance of the fixed-location hydroacoustic systems at FOS by determining deployment and dataacquisition methods that minimize structural, electrical, and acoustic interference. Optimization of the hydroacoustic systems will establish a methodology for sampling by active acoustic methods during this year-long evaluation of juvenile salmonid passage at FOS. The objectives for this optimization study were as follows:

1. Design and test mounts to deploy fixed-location hydroacoustic transducers to sample juvenile salmonid and adult steelhead passage into the spillway (regular bays and the special spillway weir), turbine penstock intakes, and vertical distribution at the forebay face of the dam.

2. Test various aiming angles and ping rates to optimize the performance of the hydroacoustic systems at the spillway, penstock, and forebay locations.

The general approach was a multi-step process from mount design to final system configuration. First, mount designs successfully utilized for previous hydroacoustic deployments in the Willamette basin were reviewed and approved by USACE engineers and project personnel at FOS. Second, we conducted field trials to perfect the mount design. Third, we tested aiming angles and ping rates in the field. And, fourth, we established the optimum configuration for each hydroacoustic system. Acoustic system configurations resulting from the optimization process are organized by deployment location (Table S.1).

Table S.1. Results of the FOS hydroacoustic optimization study.

\begin{tabular}{lcccccc}
\hline \multicolumn{1}{c}{ Location } & $\begin{array}{c}\text { Hydroacoustic } \\
\text { Equipment }\end{array}$ & $\begin{array}{c}\text { Beam } \\
\text { Width } \\
(\mathrm{deg})\end{array}$ & Mount Design & $\begin{array}{c}\text { Elevation } \\
(\mathrm{ft})\end{array}$ & $\begin{array}{c}\text { Aiming Angle } \\
(\mathrm{deg})\end{array}$ & $\begin{array}{c}\text { Ping Rate } \\
(\mathrm{pps})\end{array}$ \\
\hline $\begin{array}{l}\text { Spill bays 2 } \\
\text { and 3 }\end{array}$ & $\begin{array}{c}\text { Split-beam } \\
\text { transducers (2) }\end{array}$ & 10 & Triangle bracket & 591 & $33^{(\mathrm{a})}$ & 25 \\
$\begin{array}{l}\text { Spill bay 4 } \\
\text { weir }\end{array}$ & $\begin{array}{c}\text { Split-beam } \\
\text { transducers (4) }\end{array}$ & $\begin{array}{c}10(2) \& \\
6(2)\end{array}$ & Triangle bracket & 597 & $1^{(\mathrm{b})} \& 5^{(\mathrm{c})}$ & 25 \\
Forebay & $\begin{array}{c}\text { Single-beam } \\
\text { transducer (1) }\end{array}$ & 6 & Triangle bracket & 580 & $4^{(\mathrm{d})}$ & 25 \\
$\begin{array}{l}\text { Turbine } \\
\text { intake }\end{array}$ & $\begin{array}{c}\text { Split-beam } \\
\text { transducers (2) }\end{array}$ & 6 & $\begin{array}{c}\text { Trash rack } \\
\text { "Modified Tiltzer" }\end{array}$ & $\begin{array}{c}603.5- \\
605.5\end{array}$ & $44-50^{(\mathrm{e})}$ & 30 \\
\hline
\end{tabular}

(a) Up from horizontal with a downstream orientation.

(b) Upstream and off vertical of a plane perpendicular to the spillway face-10-deg transducers.

(c) Downstream and off vertical of a plane perpendicular to the spillway face-6-deg transducers.

(d) Upstream and off vertical of a plane perpendicular to the dam face.

(e) Up from vertical with a downstream orientation. 


\section{Preface}

This study was funded to support the fish passage evaluation at Foster Dam during 2013 and 2014 as part of the U.S. Army Corps of Engineers' (USACE's) Willamette Valley Project Program. The study was conducted by the Pacific Northwest National Laboratory (PNNL) for the USACE Portland District, whose technical leads were Dave Griffith (503.808.4773) and Fenton Khan (503.808.4777). The PNNL technical leads were James Hughes (509.371.6802), Gary Johnson (503.417.7567), and Gene Ploskey (509.427.9500). This report constitutes one of the deliverables for this project (PNNL Project No. 64283).

\section{Acknowledgments}

The authors are thankful to all who contributed to this study, including the following:

- USACE personnel at Foster Dam - Gregory Barrowcliff, Ronald Edwards, Steven Gardner, Chad Helms, Thomas Voldbaek, and other operators, engineers, and biologists at Foster Dam

- USACE personnel at the Portland District: David Griffith, Fenton Khan, and Mike Langeslay

- PNNL: Adam Flory, Mike Greiner, Julie Hughes, John Ingraham, Kathy Lavender, Brian LaMarche, Jayson Martinez, and David Parrs

- Pacific States Marine Fisheries Commission: Tyler Mitchell

- Schlosser Machine Shop: Vinnie Schlosser and staff

- United States Army 544th Engineer Dive Detachment. 


\section{Acronyms and Abbreviations}

$\begin{array}{ll}\text { deg } & \text { degrees } \\ \mathrm{El} & \text { elevation } \\ \mathrm{FOS} & \text { Foster Dam } \\ \mathrm{ft} & \text { foot(feet) } \\ \mathrm{hr} & \text { hour(s) } \\ \text { USFWS } & \text { U.S. Fish and Wildlife Service } \\ \text { min } & \text { minute(s) } \\ \text { msl } & \text { mean sea level } \\ \text { MW } & \text { megawatt } \\ \text { NMFS } & \text { National Marine Fisheries Service } \\ \text { PNNL } & \text { Pacific Northwest National Laboratory } \\ \text { PSMFC } & \text { Pacific States Marine Fisheries Commission } \\ \text { pps } & \text { pings per second } \\ \text { USACE } & \text { U.S. Army Corps of Engineers }\end{array}$




\section{Contents}

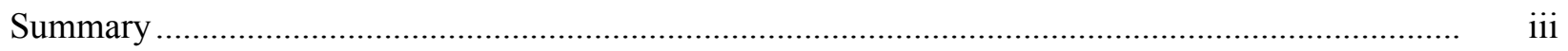

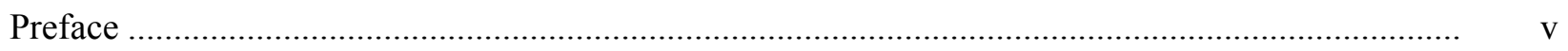

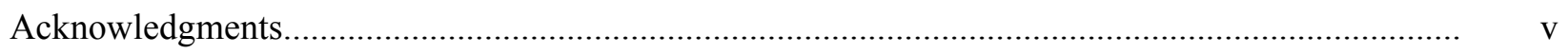

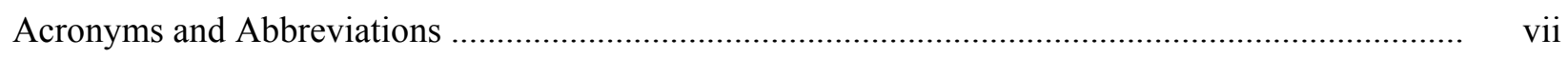

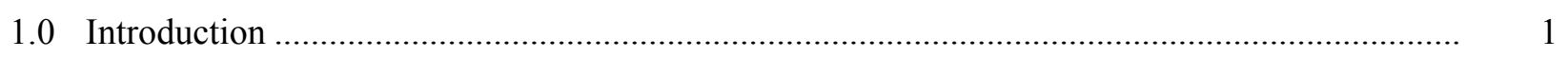

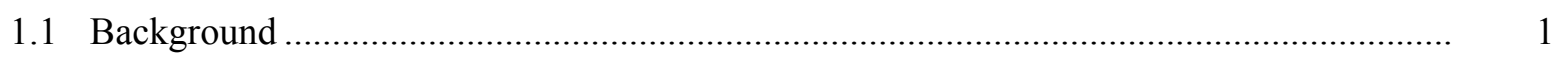

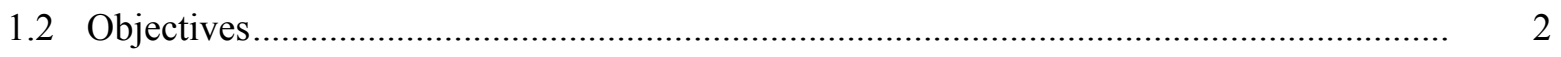

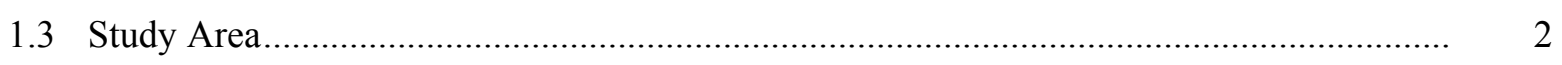

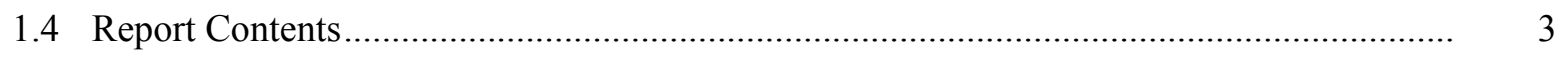

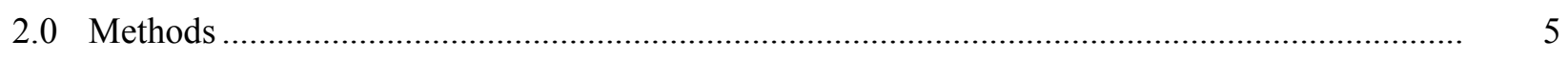

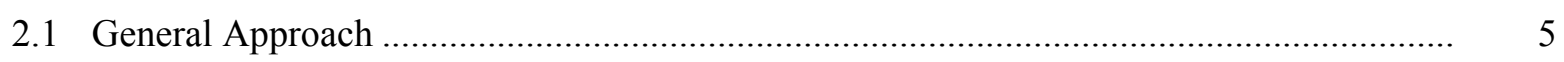

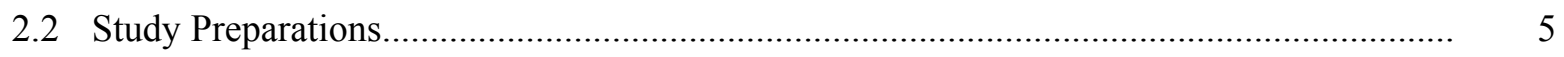

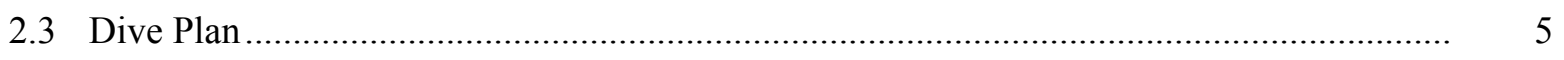

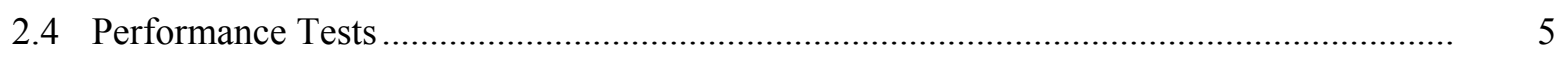

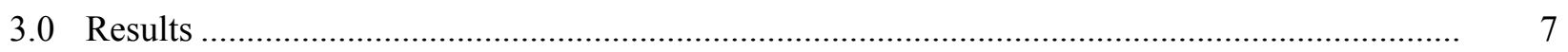

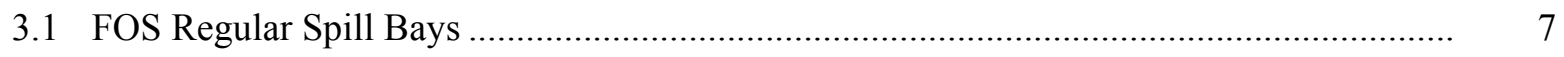

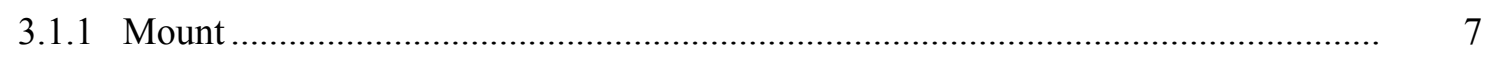

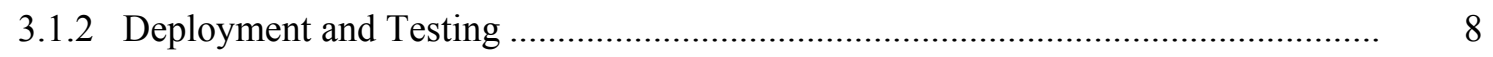

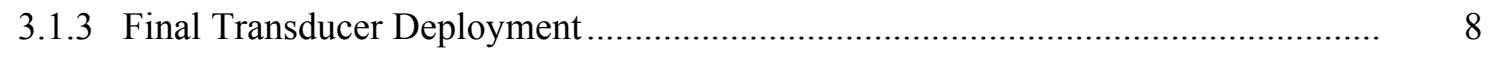

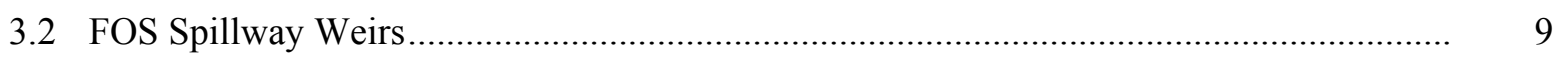

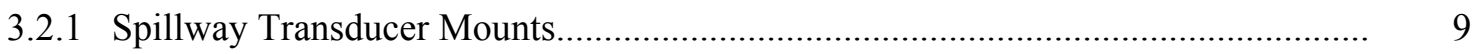

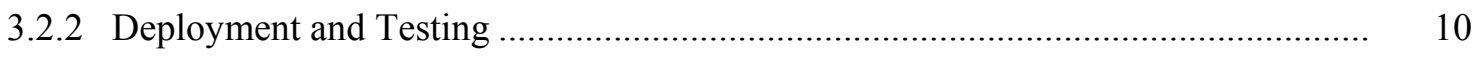

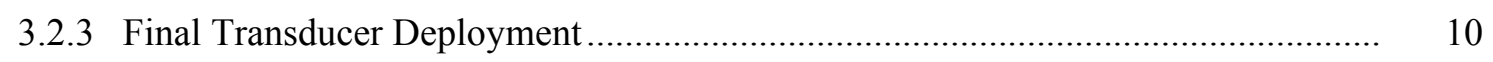

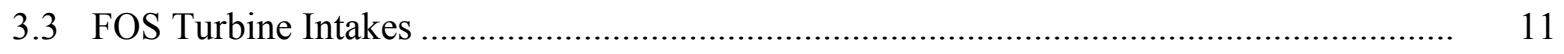

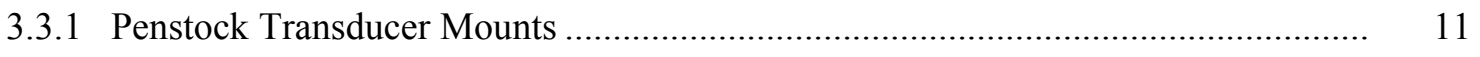

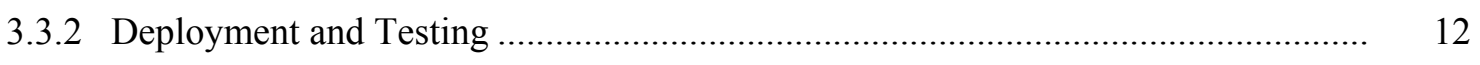

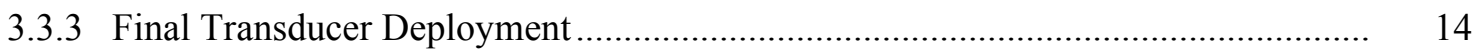

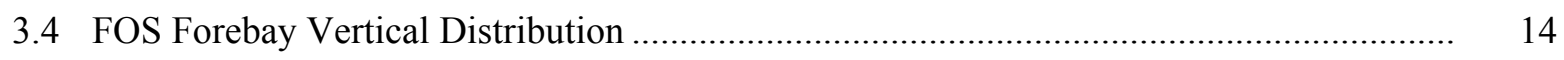

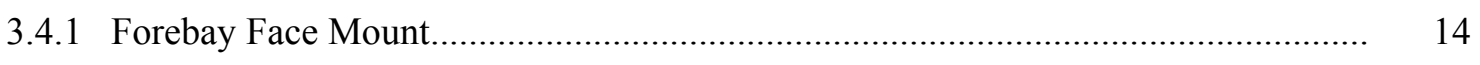

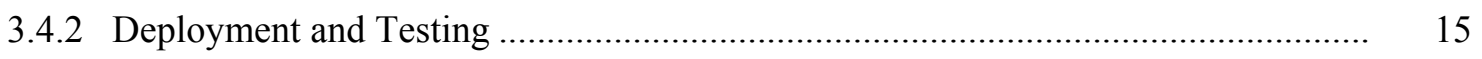

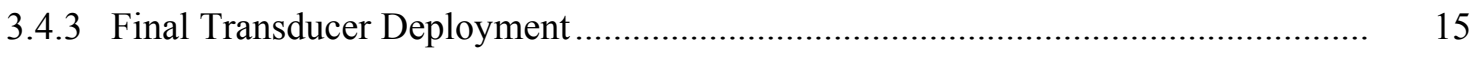

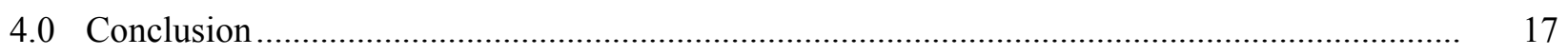

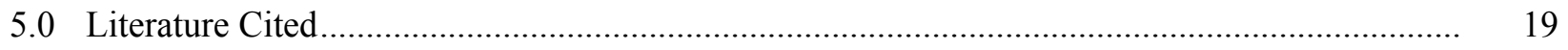




\section{Figures}

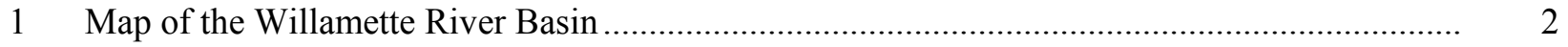

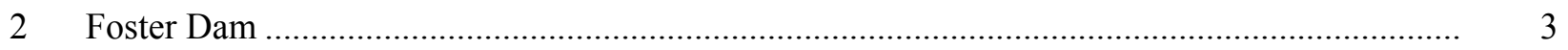

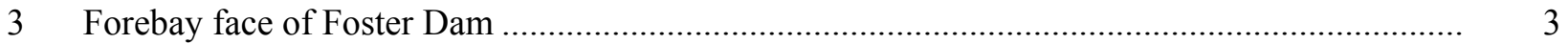

4 Front view of FOS showing transducer locations...............................................................

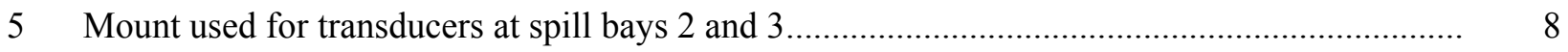

$6 \quad$ Side view of spill bay 2 and 3 transducer deployment ......................................................... 9

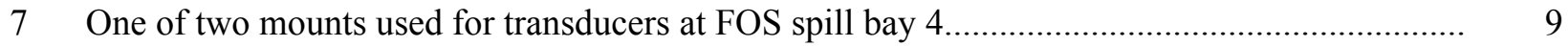

8. Side view depicting the initial orientation of the transducer and aiming angles at spill

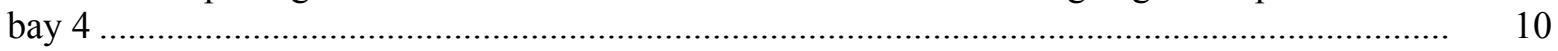

9 Front view of spill bay 4 depicting the final orientation of the transducers at the spillway

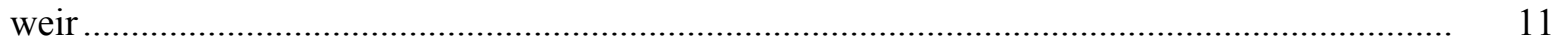

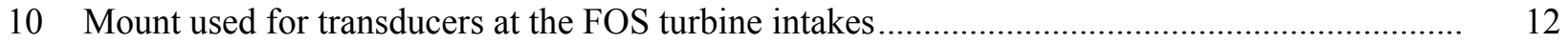

11 Side view of FOS depicting the orientation of a transducer at a turbine intake ......................... 13

12 A precision acoustics echogram of penstock 1's final deployment........................................... 13

13 A precision acoustics echogram of penstock 2's final deployment.......................................... 14

14 Mount used for vertical distribution transducer at the FOS forebay face................................... 15

15 Front view of the vertical distribution transducer deployed at the forebay face of FOS .............. 16

\section{Table}

S.1 Results of the FOS hydroacoustic optimization study ..................................................... iii

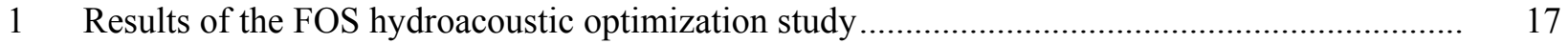




\subsection{Introduction}

This report documents the results of a hydroacoustic optimization study conducted by the Pacific Northwest National Laboratory (PNNL) and the Pacific States Marine Fisheries Commission (PSMFC) for the U.S. Army Corps of Engineers Portland District (USACE) at Foster Dam (FOS) during February and March 2013. The goal of the study was to optimize performance of the fixed-location hydroacoustic systems at FOS by determining deployment and data-acquisition methods that minimized structural, electrical, and acoustic interference. Optimization of the hydroacoustic systems will establish a methodology for sampling using active acoustic methods during the 14-month evaluation of juvenile salmonid and adult steelhead passage at FOS.

\subsection{Background}

The USACE stated in the draft research, monitoring, and evaluation plan for the Willamette Valley Project (USACE 2009) that key management questions included the following:

What are the continuing effects of the Willamette Valley Project on Willamette ecosystem function and on Endangered Species Act-listed fish species? What can effectively be done to protect, improve, restore, or mitigate for impacted species, their habitat, and related ecosystem function while also maintaining authorized Willamette Project functions?

The 2008 Willamette Project Biological Opinion requires improvements in operations and structures to reduce the impacts on Upper Willamette River Chinook and Upper Willamette River steelhead, including evaluations of the feasibility of installing new juvenile collection and bypass facilities at three Willamette River Project dams (NMFS 2008). As a part of these studies, the National Marine Fisheries Service (NMFS) and U.S. Fish and Wildlife Service (USFWS) have required that the USACE develop interim operations and investigate the feasibility of using surface flow outlets or other structures to collect and convey fish past the dams to provide safe passage for downstream migrating fish. An understanding of when, where, and how many juvenile salmonids pass into the dams, the relative passage efficiency of existing routes, and fish behavior in the forebays will be important to fisheries managers and the USACE for use in developing operations and structures that enable safe and efficient passage.

Basic information is needed to characterize juvenile salmonid and adult steelhead passage efficiencies, temporal and spatial distributions, behaviors, and movement patterns in the forebays of USACE dams in the Willamette River basin. The priority dam for research on salmonid passage during 2013 and 2014 is FOS (Figure 1). Accordingly, the USACE contracted with PNNL to conduct a 14-month fixed-location hydroacoustics study of juvenile salmonid and adult steelhead passage and behavior at FOS during 2013 and 2014. The hydroacoustic optimization study reported herein directly supports this research. Previous studies by Ploskey et al. (2002, 2008), Johnson et al. (2010), and Khan et al. (2011) provide background for the hydroacoustic optimization work described. 


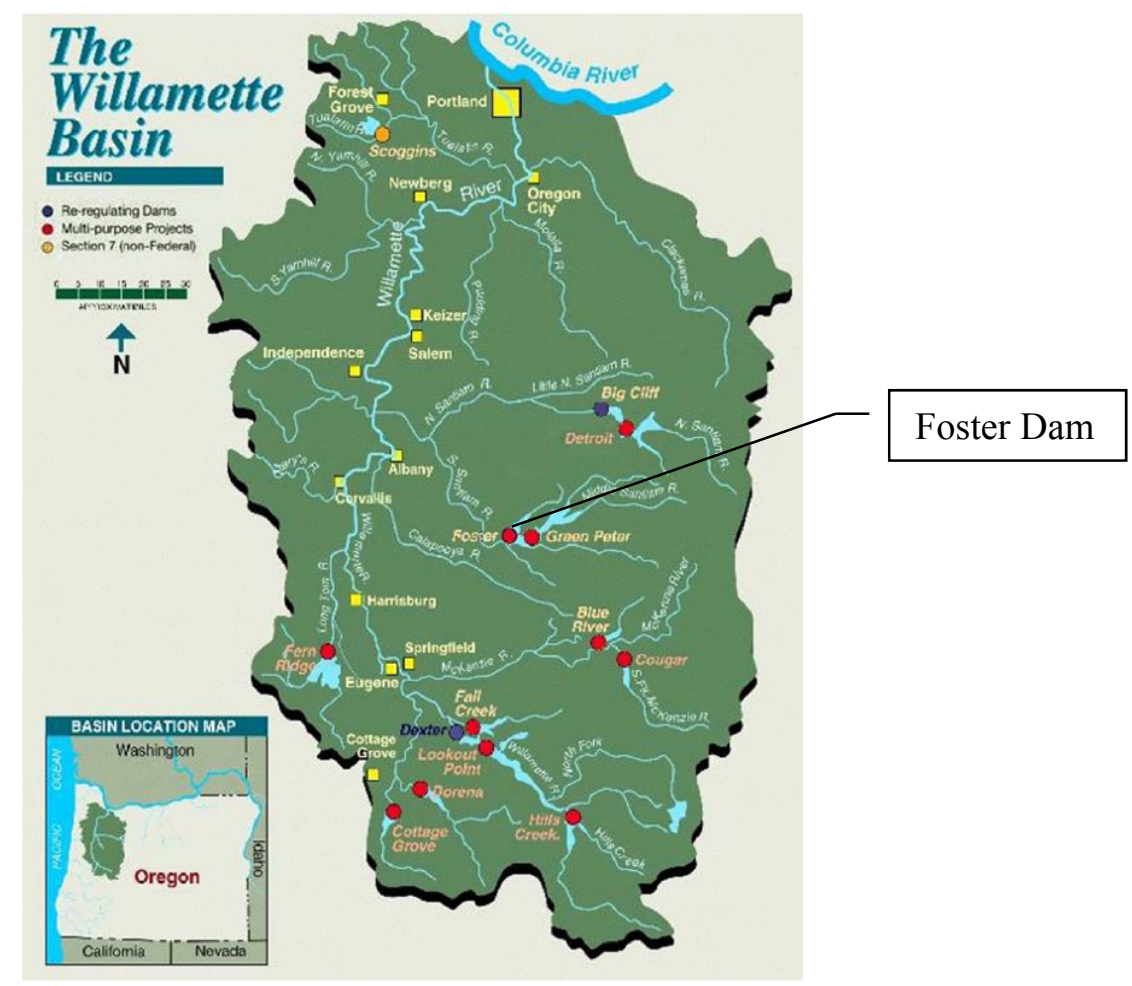

Figure 1. Map of the Willamette River Basin (NMFS 2008).

\subsection{Objectives}

The objectives of this optimization study at FOS during February and March 2013 were as follows:

1. Design and test mounts to deploy fixed-location hydroacoustic transducers to sample juvenile salmonid and adult steelhead passage into the spillway (regular bays and the special spillway weir), turbine penstock intakes, and vertical distribution at the forebay face of the dam.

2. Test various aiming angles and ping rates to optimize the performance of the hydroacoustic systems at spillway, penstock, and forebay locations.

\subsection{Study Area}

Foster Dam (Figure 2) is located on the South Santiam River near Sweet Home, Oregon. The dam consists of a powerhouse with two turbine units and a spillway with four spill bays. Spill bay 4, which is closest to the turbine intakes, is configured with a top spill weir that can be deployed on stop logs when the forebay elevation is at $614 \mathrm{ft}$ above mean sea level $(\mathrm{msl})$ and $632 \mathrm{ft}$ above msl. The primary purpose of FOS is flood control, but it also provides power (20-MW capacity), irrigation, and downstream navigation improvements. The construction of FOS created Foster Reservoir, which provides recreational and fishing opportunities. This optimization study was conducted on the forebay side of the dam at the spillway, turbine intakes, and forebay face (Figure 3). For the two turbine intake structures (also referred to as penstocks), the centerline elevation is at $590 \mathrm{ft}$ above msl, and the spillway crest elevation is at 597 $\mathrm{ft}$ above msl. The FOS minimum pool is at an elevation of $613 \mathrm{ft}$ above msl and maximum pool is $641 \mathrm{ft}$ above msl. Normal pool at FOS is at $637 \mathrm{ft}$ above msl. 


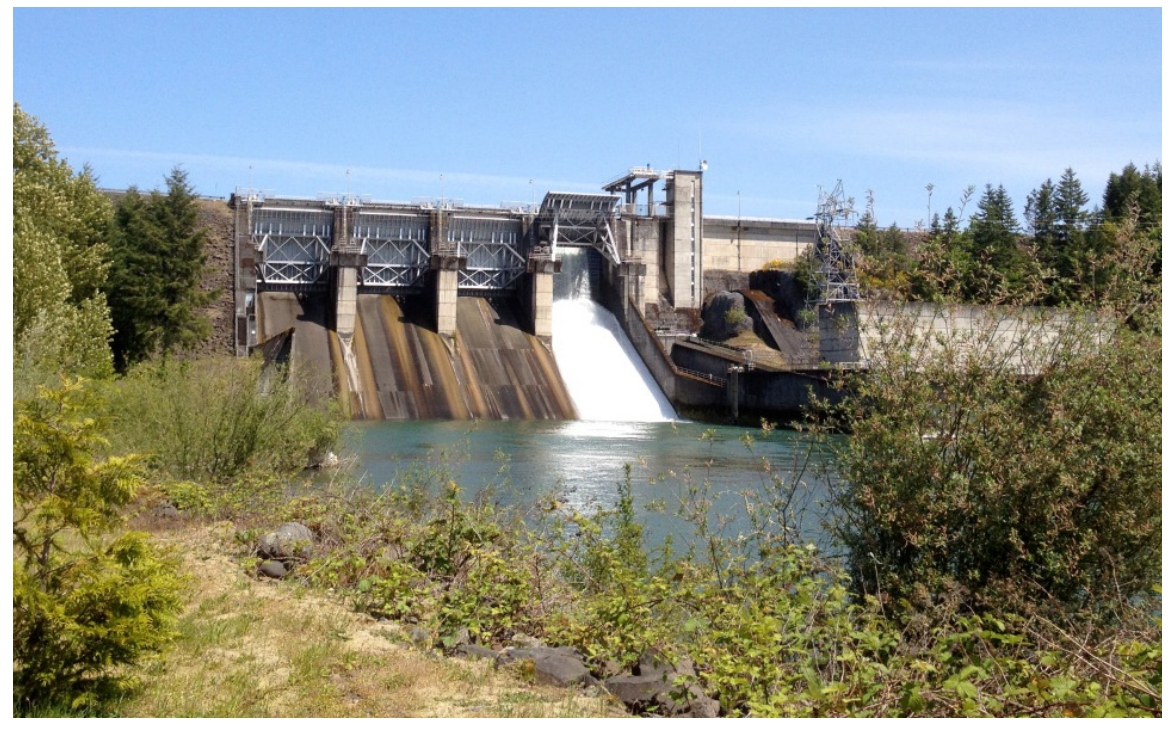

Figure 2. Foster Dam.

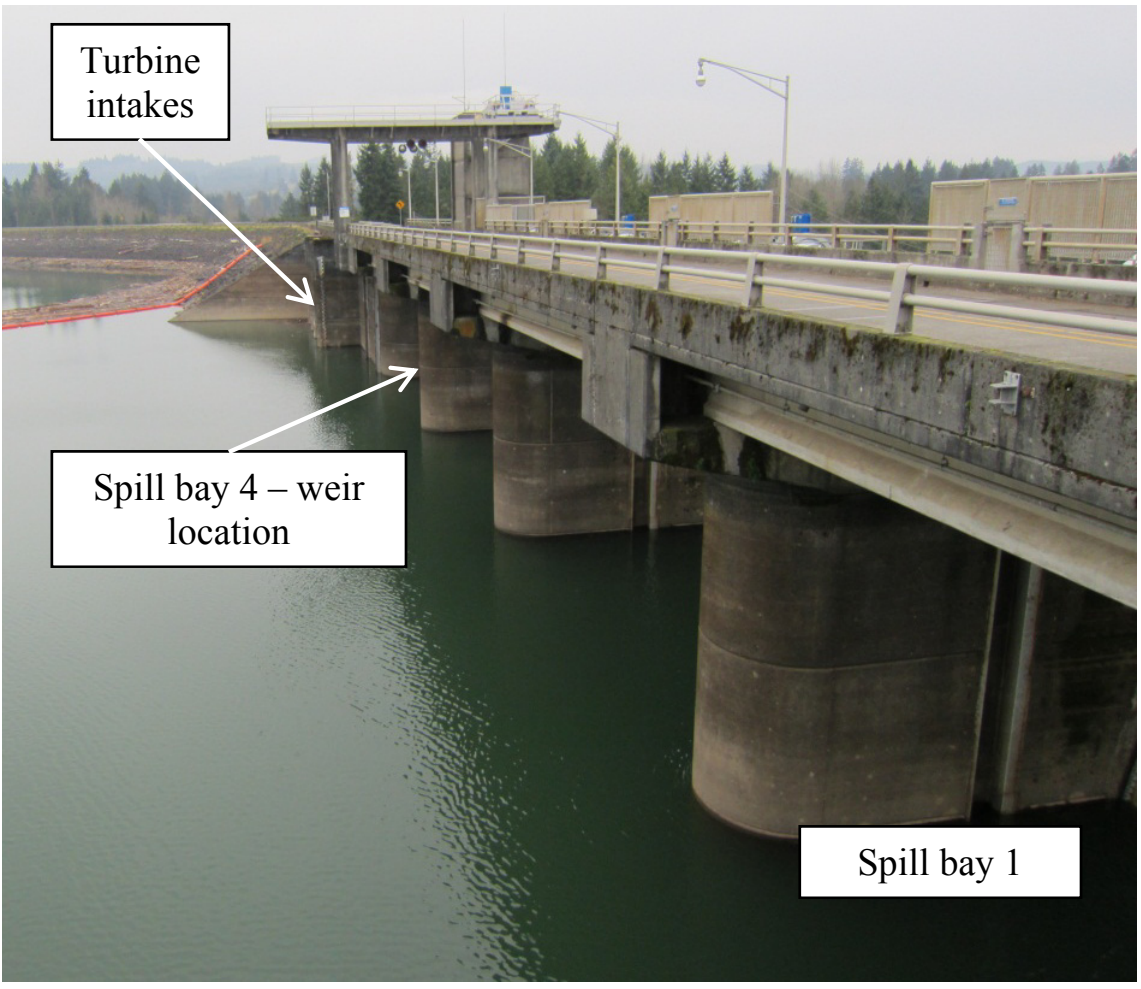

Figure 3. Forebay face of Foster Dam.

\subsection{Report Contents}

The ensuing sections of this report describe the study methods, results, and conclusions related to hydroacoustic transducer deployments and hydroacoustic system optimizations at FOS. There are no appendices. The raw data are archived at PNNL offices in Richland, Washington. 


\subsection{Methods}

The methods section includes the general approach, study preparations, dive plans, and calibrations related to optimizing the performance of systems for sampling by active acoustic methods during the 14-month-long evaluation of juvenile salmonid and adult steelhead passage at FOS.

\subsection{General Approach}

The general approach involved a multi-step process from mount design to final system configuration. First, mount designs successfully used for previous hydroacoustic deployments in the Willamette River basin (Johnson et al. 2010; Khan et al. 2011) were reviewed and approved by USACE engineers and project personnel at FOS. Second, we conducted field trials to perfect the mount design. Third, we deployed transducers at FOS and tested aiming angles and ping rates in the field. And, fourth, we established the optimum configuration for each hydroacoustic system.

\subsection{Study Preparations}

Preparation for conducting the study started with obtaining the necessary permissions and security access to the dam for all required staff. PNNL and PSMFC conducted a hazards analysis, developed a safety plan, and received a safety briefing from project personnel. Communication avenues were established between PNNL and USACE staff at the project and at USACE Portland District headquarters.

\subsection{Dive Plan}

To perform underwater mount installations at FOS, PNNL coordinated with the USACE who developed a dive plan for USACE-contracted divers (U.S. Army dive team). The dive plan is on file at the USACE Portland District. The contracted divers were from the United States Army 544th Engineer Dive Detachment.

\subsection{Performance Tests}

The fixed-location hydroacoustic equipment was performance tested before the study by PNNL at facilities in Richland, Washington. Performance test data are archived with the project records at PNNL offices in Richland, Washington. 


\subsection{Results}

The following description of results is organized by sampling location. For each location, we describe the transducer mount, deployment and optimization tests conducted, and the final deployment for optimal sampling results. A front view of the deployments of hydroacoustic transducers from the forebay at FOS looking downstream is shown in the drawing in Figure 4.

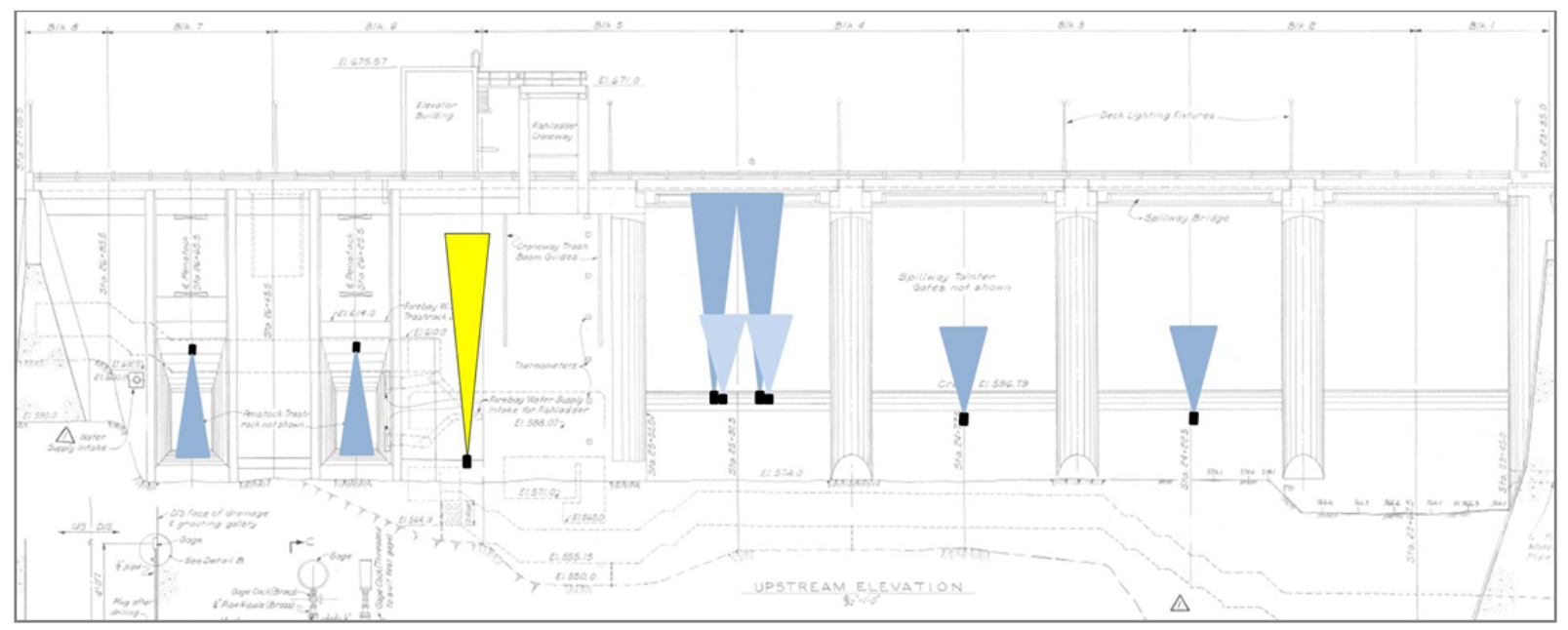

Figure 4. Front view of FOS showing transducer locations.

\subsection{FOS Regular Spill Bays}

The purpose of the transducers mounted at the regular spill bays (i.e., spill bays without weirs) is to estimate the passage rates of juvenile salmonids and adult steelhead through these bays. Transducers were successfully deployed at bays 2 and 3. Because of the inability to shut off a water supply line feeding a downstream hatchery, the USACE decided that no dive work could be conducted in spill bay 1 , so no transducer was installed in spill bay 1 .

\subsubsection{Mount}

The mount for the transducers for the regular spill bays (Figure 5) consists of a triangular base attached to the concrete face of the dam with concrete anchors. A stanchion with a right-angle bracket was welded to the base. A stainless steel cage containing a split-beam transducer was attached to the bracket. 


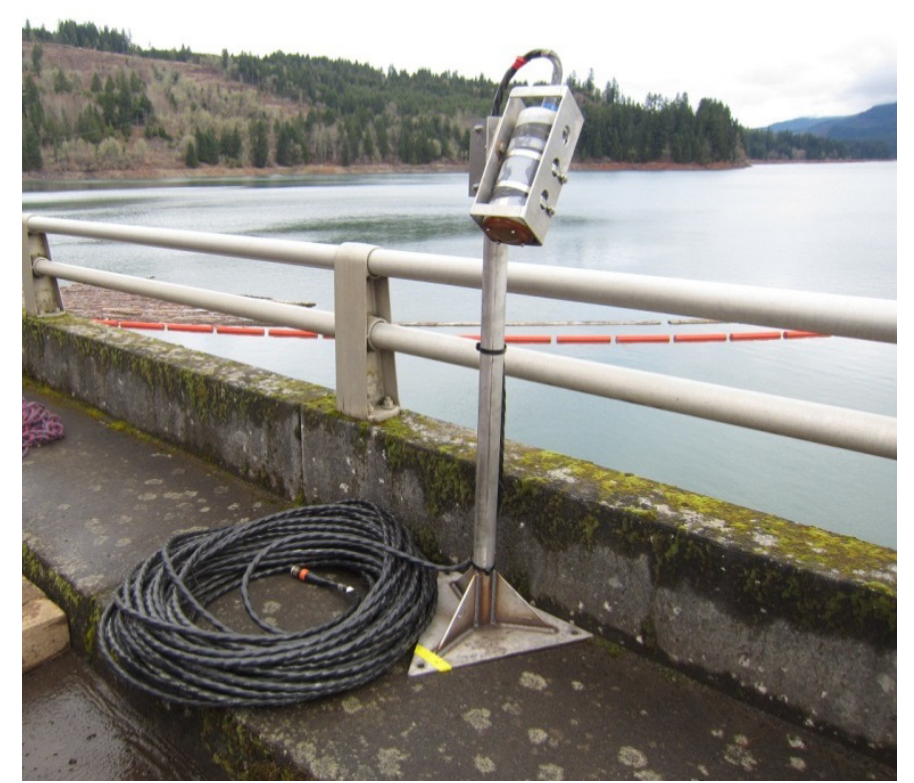

Figure 5. Mount used for transducers at spill bays 2 and 3.

\subsubsection{Deployment and Testing}

From February 18 through 22, 2013, divers installed the mount/transducer assemblies at spill bays 2 and 3. Tests were conducted by transmitting sound energy ("pinging") at 25 pings per second (pps) and examining the data for echoes from the target. Echograms depicting hard structures at expected distances would imply that the transducer deployment was optimal.

\subsubsection{Final Transducer Deployment}

The optimal deployment for the regular spill bay transducers was an up-looking 10-deg split-beam transducer aimed $33 \mathrm{deg}$ up from the horizontal plane with a downstream orientation (Figure 6). The two spill bay transducers will transmit at 25 pps and sample alternately on a 2-min schedule for approximately $30 \mathrm{~min} / \mathrm{hr}$ each. Spatial expansion of detections will depend upon the range of detection from a transducer and the ratio of the distance across the opening perpendicular to the main axis of the acoustic beam. Given the aiming angle across the rectangular openings, the distance across the opening perpendicular to the beam axis will have to be entered in a lookup table for every possible range of detection. 


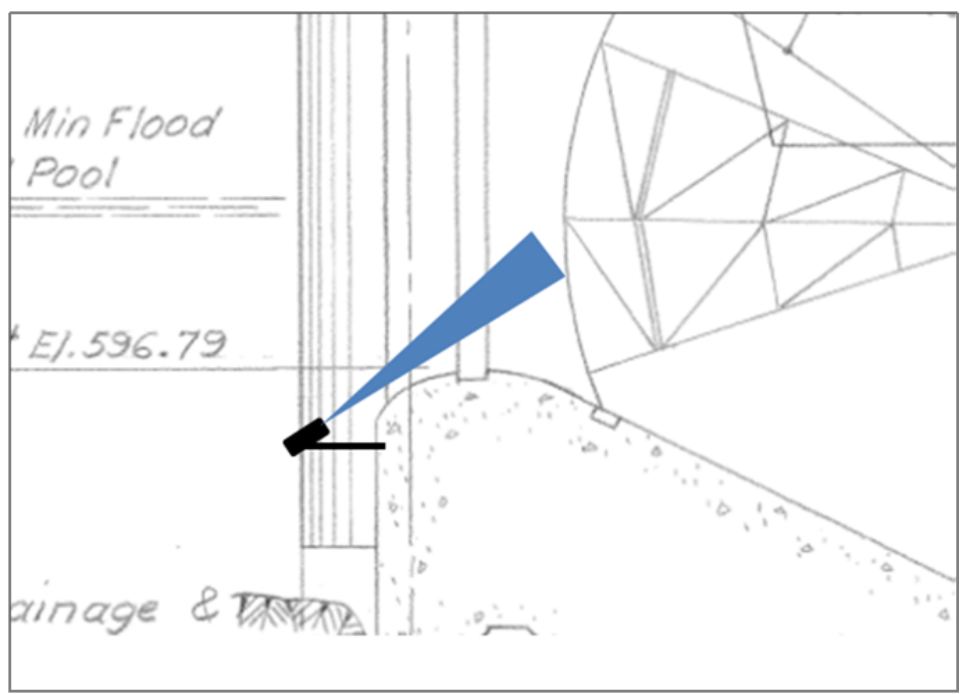

Figure 6. Side view of spill bay 2 and 3 transducer deployment.

\subsection{FOS Spillway Weirs}

The purpose of the transducers in spill bay 4 at FOS is to estimate the passage rates of juvenile salmonids and adult steelhead over the top spill weir deployed at two elevations ( $614 \mathrm{ft}$ above msl and $632 \mathrm{ft}$ above $\mathrm{msl})$.

\subsubsection{Spillway Transducer Mounts}

The mounts for the spillway weir transducers (Figure 7) consist of a triangular base attached to the concrete face of the dam with concrete anchors. A stanchion with a right-angle bracket was welded to the base. Two aluminum cages containing split-beam transducers were attached to the bracket.

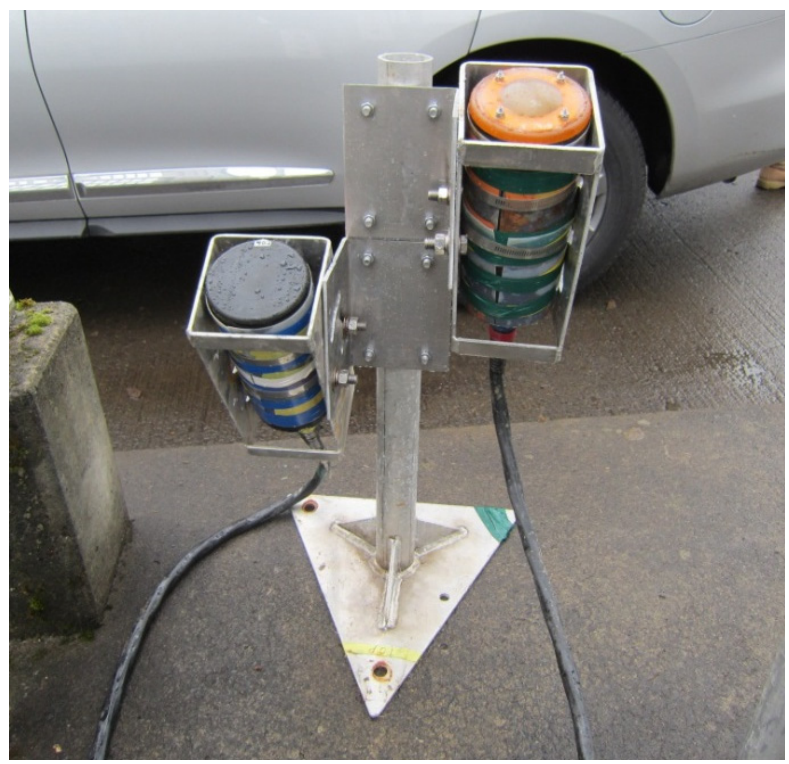

Figure 7. One of two mounts used for transducers at FOS spill bay 4. 


\subsubsection{Deployment and Testing}

Because spill bay 4 has been adapted to accommodate a removable weir, an alternate deployment for this bay had to be explored to ensure adequate detection of passing juvenile salmonids and adult steelhead. Because this weir can be deployed when the forebay elevation is at $614 \mathrm{ft}$ above msl and $632 \mathrm{ft}$ above msl, two different vertical locations of interest must be adequately sampled at any given time during the study period. To ensure adequate coverage, two transducer mounts were deployed with two transducers per mount (Figure 7). Figure 8 depicts the sampling area for each weir deployment elevation. For each mount, one transducer was a 6-deg split-beam transducer aimed 5 deg downstream of vertical, while the other transducer was a 10-deg split-beam transducer aimed 1 deg upstream of vertical.

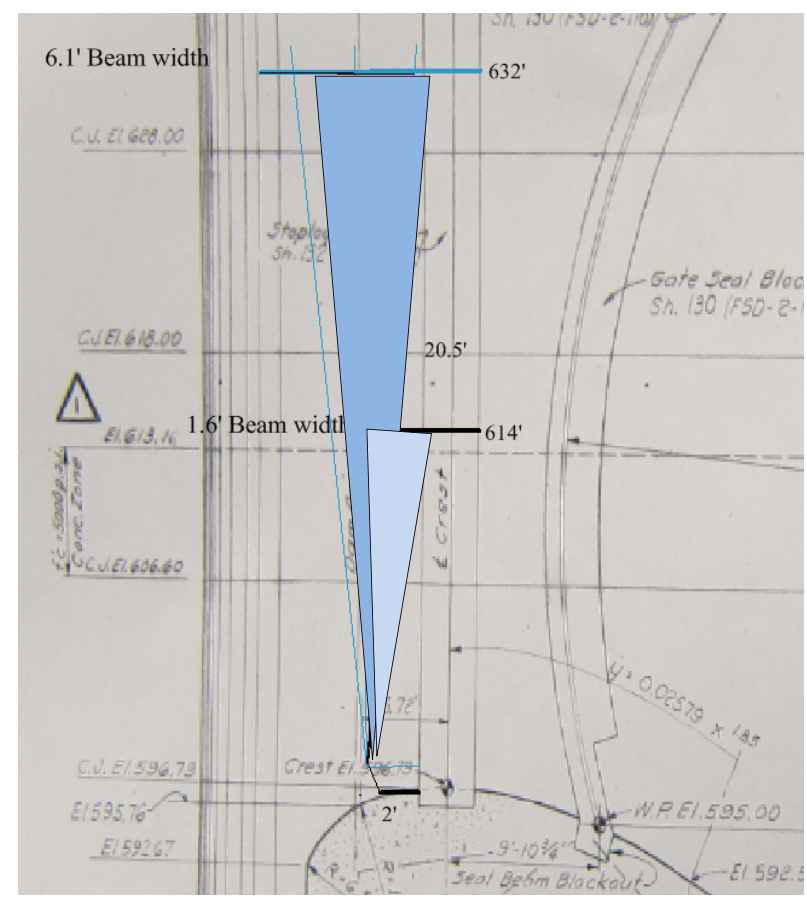

Figure 8. Side view depicting the initial orientation of the transducer and aiming angles (black and blue lines) at spill bay 4 .

\subsubsection{Final Transducer Deployment}

The optimal deployment for spill bay 4 transducers was two 6-deg split-beam transducers aimed $5 \mathrm{deg}$ downstream of vertical (optimally aimed for weir deployment at $614 \mathrm{ft}$ above msl) and two 10-deg split-beam transducers aimed $1 \mathrm{deg}$ upstream of vertical (optimally aimed for weir deployment at $632 \mathrm{ft}$ above msl (Figure 8 and Figure 9)). The spillway weir transducers will transmit at 25 pps and be sampled for 30 min each per hour depending on the elevation being sampled. Spatial expansion of detections will depend upon the range of detection from a transducer and the ratio of the distance across the opening perpendicular to the main axis of the acoustic beam. Given the aiming angle across the rectangular openings, the distance across the opening perpendicular to the beam axis will have to be entered in a lookup table for every possible range of detection. 


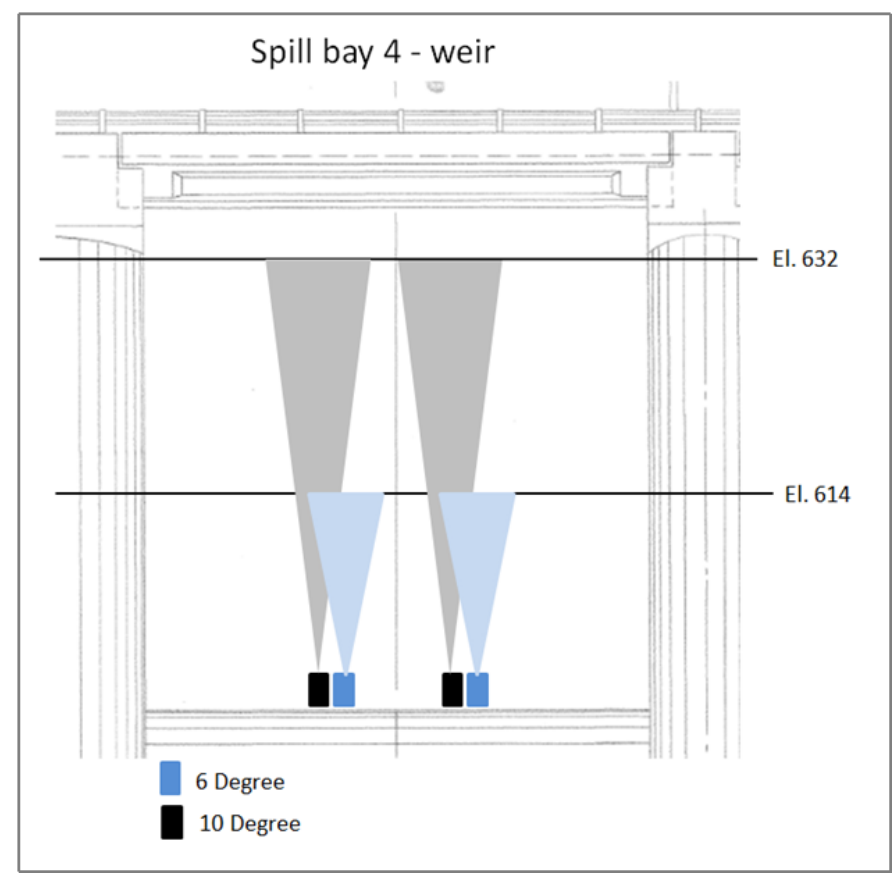

Figure 9. Front view of spill bay 4 depicting the final orientation of the transducers at the spillway weir.

\subsection{FOS Turbine Intakes}

The purpose of the transducers inside the penstocks at FOS is to estimate passage rates of juvenile salmonids into the two turbine units.

\subsubsection{Penstock Transducer Mounts}

The mount for the penstock transducers consisted of a base with an adjustable arm (Figure 10). A cage for the transducer was attached to the arm. An in-line screw mechanism allowed divers to adjust the aiming angle. Anchor chains were attached to the mount and subsequently to the trash rack to prevent the assembly from moving into the penstock if it came loose from the trash rack.

The transducer mounts for the FOS turbine intakes were designed to fit between the vertical bars of the trash rack. This design allowed divers to secure the mount with "J" bolts to the trash rack of each intake from the forebay. 


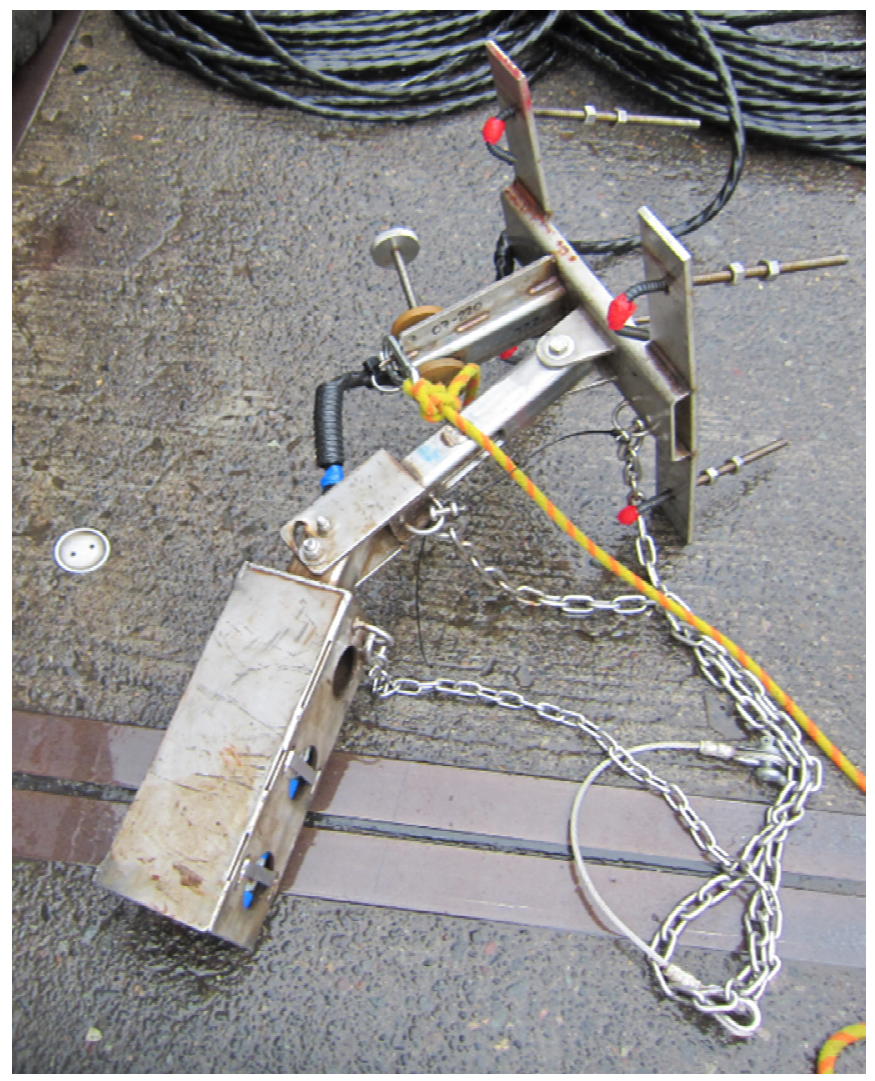

Figure 10. Mount used for transducers at the FOS turbine intakes.

\subsubsection{Deployment and Testing}

As with previous penstock deployments at other Willamette Valley projects, ideal deployment for penstock transducers would have been uplookers looking directly at the ceiling of the turbine intake. This deployment method is preferred because fish will be committed to passing when sampled. However, buildup of woody debris near the bottom of the trash racks may be problematic as it was at both Lookout Point and Detroit Dams (Khan et al. 2012a, 2012b). Therefore, deployment at the penstocks at FOS was similar to that of previous projects, and transducers were deployed in a down-looking orientation.

Penstock 1: The location for sampling penstock 1 passage was very near the top of the upper most trash rack (603.5 ft above msl; Figure 11). The transducer initially was aimed up from vertical 40 deg with a downstream orientation. After the divers finished the installation and the head gate was removed, a variety of ping rates were tested to select the best rate. An acoustic echogram from penstock 1 (Figure 12) clearly shows conducive aiming angles with a transducer optimally aimed directly into the penstock. 


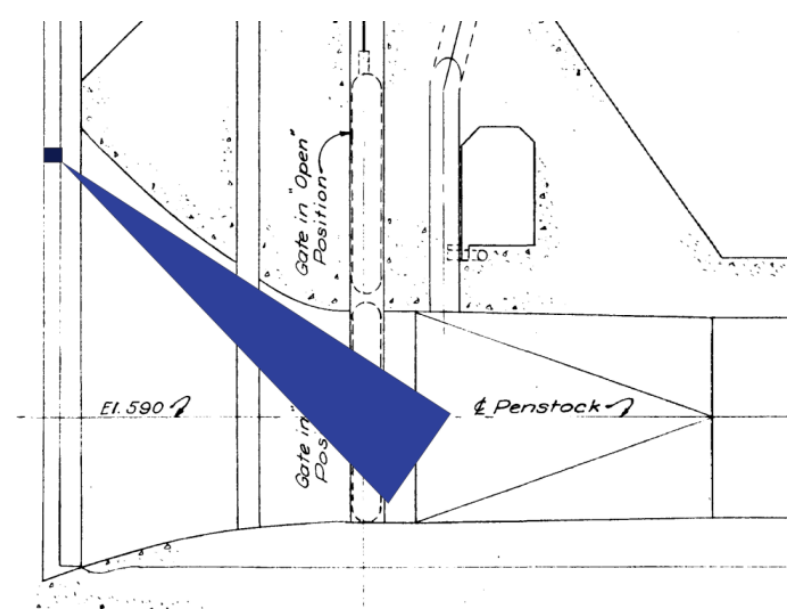

Figure 11. Side view of FOS depicting the orientation of a transducer at a turbine intake.

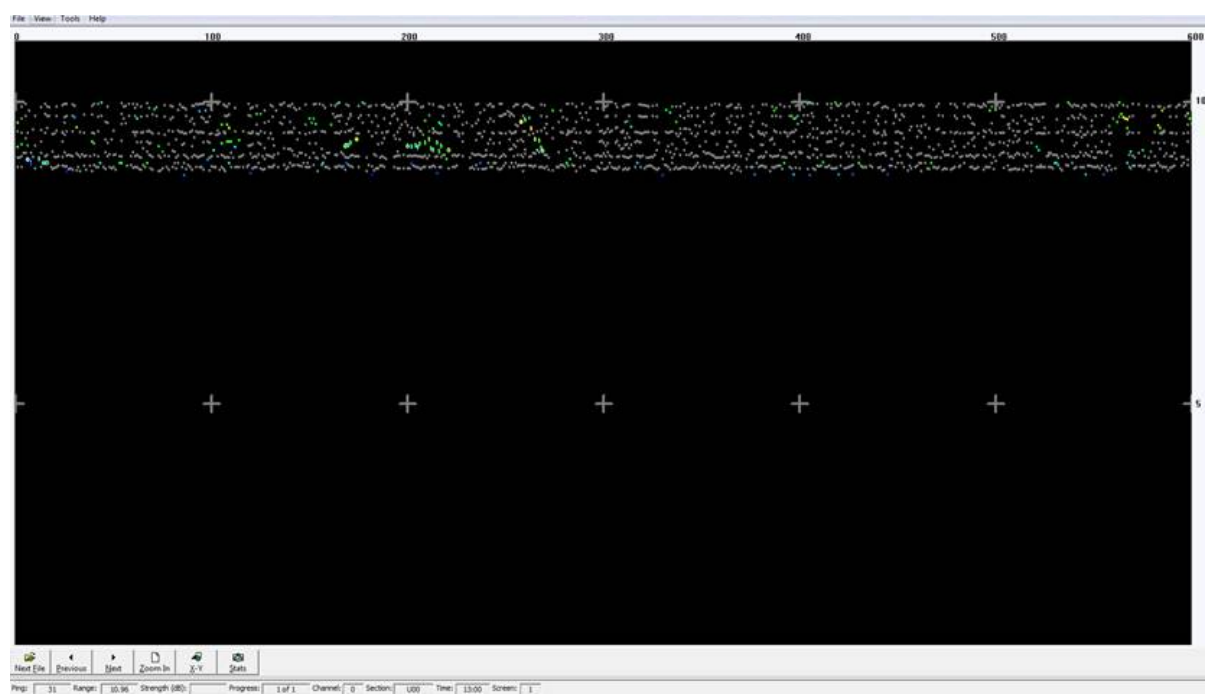

Figure 12. A precision acoustics echogram of penstock 1's final deployment.

Penstock 2: The location for sampling penstock 2 was similar to that of penstock 1: very near the top of the upper most trash rack (605.5 ft above msl; Figure 11). Aiming angles and post-deployment echograms were also similar to that of penstock 1. However, penstock 2's transducer was removed from its originally deployed position to support FOS project work, and it was replaced at the end of February 2013. The resulting echogram (Figure 13) depicts the orientation of a transducer aimed at 50 deg up from vertical with a downstream orientation. Although the final aiming angle for penstock 2 does not appear to be similar to that of the original deployment, we are confident that this transducer is aimed sufficiently to accurately estimate fish passage through penstock 2 . Note the intermittent hard structure at $4.5 \mathrm{~m}$ on the echogram. We believe this structure to be the penstock intake ceiling, indicating we will be sampling near the top of the penstock opening as desired. 


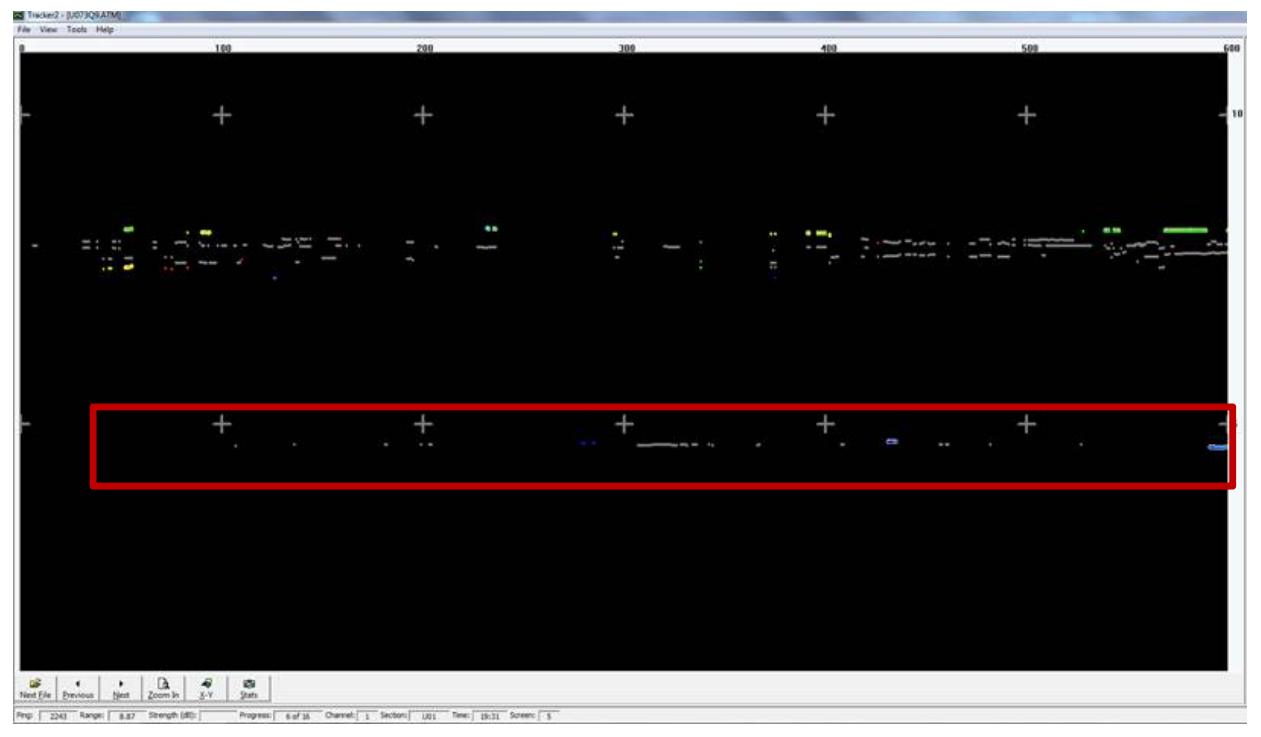

Figure 13. A precision acoustics echogram of penstock 2's final deployment. The red box highlights an intermittent hard structure believed to be the intake ceiling.

\subsubsection{Final Transducer Deployment}

The final deployment for the penstock 1 transducer was a down-looking, 6-deg split-beam transducer aimed 44 deg downstream from vertical (Figure 11) and for penstock 2 was a 6-deg split-beam transducer aimed approximately $50 \mathrm{deg}$ downstream from vertical. The two turbine intake transducers will transmit at $30 \mathrm{pps}$ and sample alternately on a 2 -min schedule for approximately $29 \mathrm{~min} / \mathrm{hr}$ (2 minute idle period at the top of every hour).

\subsection{FOS Forebay Vertical Distribution}

The purpose of the transducer at the forebay face at FOS is to estimate the vertical distribution of fish in the immediate forebay of the dam.

\subsubsection{Forebay Face Mount}

The single mount deployed between the powerhouse and spillway, used for vertical distribution, was similar to that of the ones deployed at spill bay 4 but with only one transducer (Figure 14). 


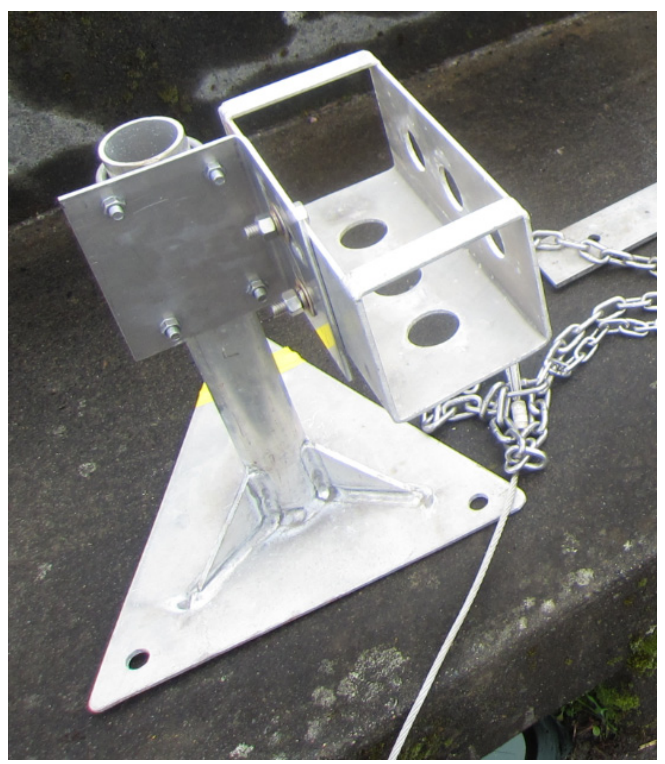

Figure 14. Mount used for vertical distribution transducer at the FOS forebay face.

\subsubsection{Deployment and Testing}

For this deployment, we proposed to deploy one up-looking, 6-deg, single-beam transducer on the concrete face of the dam, near the bottom ( $580 \mathrm{ft}$ above $\mathrm{msl}$ ), between the penstock intakes and the spillway. This transducer would be aimed 4 deg upstream to ensure the sampling volume was immediately upstream of the dam face.

\subsubsection{Final Transducer Deployment}

The optimal deployment for the forebay vertical distribution transducer was a single, 6-deg transducer aimed 4 deg upstream from the vertical plane of the dam face and up looking from a deployed elevation of $580 \mathrm{ft}$ above msl (Figure 15). This single beam transducer will transmit at $25 \mathrm{pps}$ and sample for 4 3 -min collection periods and then idle for $3 \mathrm{~min}$ for a total sample of approximately $45 \mathrm{~min} / \mathrm{hr}$. 


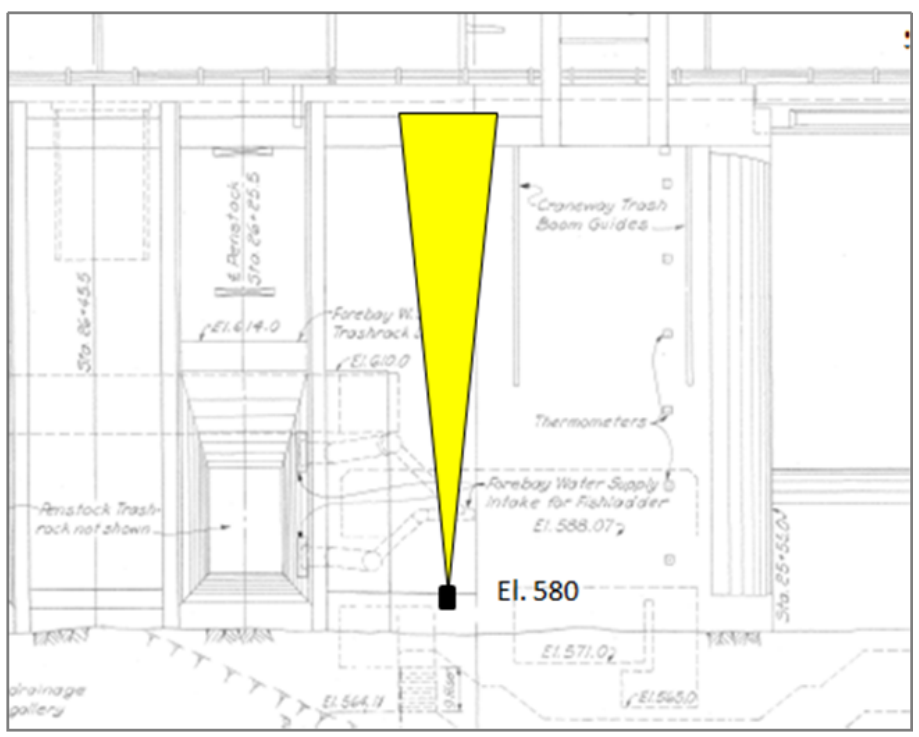

Figure 15. Front view of the vertical distribution transducer deployed at the forebay face of FOS. 


\subsection{Conclusion}

This report described the acoustic optimization study conducted at FOS during February and March 2013. The study provided valuable insight into how to sample successfully using underwater acoustic systems.

Optimization can be achieved by limiting interference to hydroacoustic systems using several approaches, including the placement and aiming angles of transducers and, the ping rates of echo sounders. PNNL pursued all of these approaches in the study reported herein. Table 1 lists the system configurations established for the 14-month-long hydroacoustic study at FOS. In conclusion, the optimization effort resulted in successful deployments of hydroacoustic equipment at FOS during 2013.

Table 1. Results of the FOS hydroacoustic optimization study.

\begin{tabular}{|c|c|c|c|c|c|c|}
\hline Location & $\begin{array}{c}\text { Hydroacoustic } \\
\text { Equipment }\end{array}$ & $\begin{array}{l}\text { Beam } \\
\text { Width } \\
(\text { deg) }\end{array}$ & Mount Design & $\begin{array}{l}\text { Elevation } \\
\quad(\mathrm{ft})\end{array}$ & $\begin{array}{l}\text { Aiming Angle } \\
(\mathrm{deg})\end{array}$ & $\begin{array}{l}\text { Ping Rate } \\
\text { (pps) }\end{array}$ \\
\hline $\begin{array}{l}\text { Spill } \\
\text { bays } 2 \text { and } \\
3\end{array}$ & $\begin{array}{c}\text { Split-beam } \\
\text { transducers (2) }\end{array}$ & 10 & Triangle bracket & 591 & $33^{(a)}$ & 25 \\
\hline $\begin{array}{l}\text { Spill bay } 4 \\
\text { weir }\end{array}$ & $\begin{array}{c}\text { Split-beam } \\
\text { transducers (4) }\end{array}$ & $\begin{array}{c}10(2) \& \\
6(2)\end{array}$ & Triangle bracket & 597 & $1^{(\mathrm{b})} \& 5^{(\mathrm{c})}$ & 25 \\
\hline Forebay & $\begin{array}{l}\text { Single-beam } \\
\text { transducer (1) }\end{array}$ & 6 & Triangle bracket & 580 & $4^{(\mathrm{d})}$ & 25 \\
\hline $\begin{array}{l}\text { Turbine } \\
\text { intake }\end{array}$ & $\begin{array}{c}\text { Split-beam } \\
\text { transducers (2) }\end{array}$ & 6 & $\begin{array}{c}\text { Trash rack } \\
\text { "Modified Tiltzer" }\end{array}$ & $\begin{array}{c}603.5- \\
605.5\end{array}$ & $44-50^{(\mathrm{e})}$ & 30 \\
\hline
\end{tabular}

(a) Up from horizontal with a downstream orientation.

(b) Upstream and off vertical of a plane perpendicular to the spillway face-10-deg transducers.

(c) Downstream and off vertical of a plane perpendicular to the spillway face-6-deg transducers.

(d) Upstream and off vertical of a plane perpendicular to the dam face.

(e) Up from vertical with a downstream orientation. 


\subsection{Literature Cited}

National Marine Fisheries Service. 2008. Willamette River Basin Flood Control Project. Biological Opinion. July 11, 2008, National Marine Fisheries Service, Northwest Region, Seattle, Washington.

Johnson GE, F Khan, GR Ploskey, JS Hughes, and ES Fischer. 2010. Optimization of Hydroacoustic Equipment Deployments at Lookout Point and Cougar Dams, Willamette Valley Project, 2010.

PNNL-19293, prepared for the U.S. Army Corps of Engineers, Portland District, Portland, Oregon, by the Pacific Northwest National Laboratory, Richland, Washington,

Khan F, IM Royer, JS Hughes, ES Fischer, GE Johnson, and GR Ploskey. 2011. Optimization of Hydroacoustic Equipment Deployment at Detroit Dam, 2011. PNNL-20498, prepared for the U.S. Army Corps of Engineers, Portland District, Portland, Oregon, by the Pacific Northwest National Laboratory, Richland, Washington,

Khan F, GE Johnson, IM Royer, JS Hughes, ES Fischer, DM Trott, and GR Ploskey. 2012a. Hydroacoustic Evaluation of Juvenile Salmonid Passage and Distribution at Lookout Point Dam, 2010. PNNL-20362, prepared for the U.S. Army Corps of Engineers, Portland District, Portland, Oregon, by the Pacific Northwest National Laboratory, Richland, Washington.

Khan F, IM Royer, GE Johnson, and KD Ham. 2012b. Hydroacoustic Evaluation of Juvenile Salmonid Passage and Distribution at Detroit Dam, 2011. PNNL-21577, prepared for the U.S. Army Corps of Engineers, Portland District, Portland, Oregon, by the Pacific Northwest National Laboratory, Richland, Washington.

Ploskey GR, CB Cook, PS Titzler, and RA Moursund. 2002. Optimization of Hydroacoustic Deployments at John Day Dam. PNNL-14062, prepared for the U.S. Army Corps of Engineers, Portland District, Portland, Oregon, by the Pacific Northwest National Laboratory, Richland, Washington.

Ploskey GR, JS Hughes, F Khan, J Kim, BL LaMarche, GE Johnson, EY Choi, DM Faber, MC Wilberding, Z Deng, MA Weiland, SA Zimmerman, ES Fischer, and AW Cushing. 2008. Optimization of Concurrent Deployments of the Juvenile Salmon Acoustic Telemetry System and Other Hydroacoustic Equipment at John Day Dam. PNNL-17837, prepared for the U.S. Army Corps of Engineers, Portland District, Portland, Oregon, by the Pacific Northwest National Laboratory, Richland, Washington.

USACE (U.S. Army Corps of Engineers). 2009. "Comprehensive Plan For Research, Monitoring, and Evaluation in the Willamette River Basin.” DRAFT report, U.S. Army Corps of Engineers, Portland District, Portland, Oregon. 
PNNL-22359

\section{Distribution}

No. of PDF and Hard

Copies

\section{OFFSITE}

2 Dave Griffith

U.S. Army Corps of Engineers

P.O. Box 2946

Portland, OR 97208

Fenton Khan

U.S. Army Corps of Engineers

P.O. Box 2946

Portland, OR 97208
No. of PDF and Hard

Copies

\section{ONSITE}

5 Pacific Northwest National Laboratory

ES Fischer

NBON

JS Hughes

K6-85

GE Johnson

BPO

GR Ploskey

NBON

SA Zimmerman 


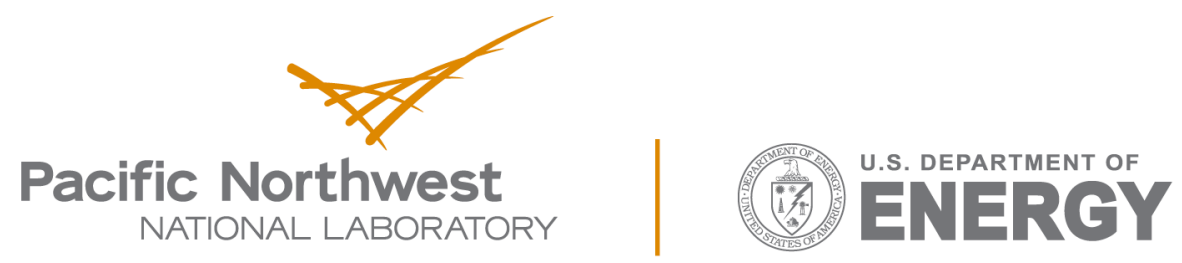

Proudly Operated by Battelle Since 1965

902 Battelle Boulevard

P.O. Box 999

Richland, WA 99352

1-888-375-PNNL (7665)

www.pnnl.gov 